\title{
Chitin-Lignin Material as a Novel Matrix for Enzyme Immobilization
}

\section{Jakub Zdarta ${ }^{\mathbf{1}}$, Lukasz Klapiszewski ${ }^{1}$, Marcin Wysokowski ${ }^{\mathbf{1}}$, Małgorzata Norman ${ }^{\mathbf{1}}$, Agnieszka Kołodziejczak-Radzimska ${ }^{1}$, Dariusz Moszyński ${ }^{2}$, Hermann Ehrlich ${ }^{3}$, Hieronim Maciejewski ${ }^{4,5}$, Allison L. Stelling ${ }^{6}$ and Teofil Jesionowski ${ }^{1, *}$}

1 Institute of Chemical Technology and Engineering, Faculty of Chemical Technology, Poznan University of Technology, Berdychowo 4, 60965 Poznan, Poland;

E-Mails: jakub_zdarta@wp.pl (J.Z.); lukasz.klapiszewski@put.poznan.pl (L.K.); wysokowski@wp.pl (M.W.); malgorzata.norman@hotmail.com (M.N.); agnieszka.kolodziejczak-radzimska@ put.poznan.pl (A.K.-R.)

2 Institute of Inorganic Chemical Technology and Environmental Engineering, West Pomeranian University of Technology, Pulaskiego 10, 70322 Szczecin, Poland; E-Mail: dmoszynski@zut.edu.pl

3 Institute of Experimental Physics, TU Bergakademie Freiberg, Leipziger Str. 23, 09599 Freiberg, Germany; E-Mail: Hermann.Ehrlich@physik.tu-freiberg.de

4 Adam Mickiewicz University in Poznan, Faculty of Chemistry, Umultowska 89b, 61614 Poznan, Poland; E-Mail: maciejm@ amu.edu.pl

5 Poznan Science and Technology Park, Adam Mickiewicz University Fundation, Rubież 46, 61612 Poznan, Poland

6 Duke University, Center for Materials Genomics, Department of Mechanical Engineering and Materials Science,144 Hudson Hall, Durham, NC 27708, USA; E-Mail: antistokes@ gmail.com

* Author to whom correspondence should be addressed; E-Mail: teofil.jesionowski@ put.poznan.pl; Tel.: +48-61-665-37-20; Fax: +48-61-665-36-49.

Academic Editor: Paola Laurienzo

Received: 19 February 2015 / Accepted: 27 March 2015 / Published: 20 April 2015

Abstract: Innovative materials were made via the combination of chitin and lignin, and the immobilization of lipase from Aspergillus niger. Analysis by techniques including FTIR, XPS and ${ }^{13} \mathrm{C}$ CP MAS NMR confirmed the effective immobilization of the enzyme on the surface of the composite support. The electrokinetic properties of the resulting systems were also determined. Results obtained from elemental analysis and by the Bradford method enabled the determination of optimum parameters for the immobilization process. Based on the hydrolysis reaction of para-nitrophenyl palmitate, a determination was made 
of the catalytic activity, thermal and $\mathrm{pH}$ stability, and reusability. The systems with immobilized enzymes were found to have a hydrolytic activity of $5.72 \mathrm{mU}$, and increased thermal and $\mathrm{pH}$ stability compared with the native lipase. The products were also shown to retain approximately $80 \%$ of their initial catalytic activity, even after 20 reaction cycles. The immobilization process, using a cheap, non-toxic matrix of natural origin, leads to systems with potential applications in wastewater remediation processes and in biosensors.

Keywords: chitin-lignin matrix; enzyme immobilization; hydrolytic activity; lipase; immobilized lipase stability

\section{Introduction}

Continuing technological progress means that scientists are constantly finding new solutions that make use of lignin and its derivatives. When suitably modified, lignin is a polarographically active material [1] capable of undergoing a variety of electrochemical reactions, in the course of both oxidation and reduction [2]. Consequently, in recent years it has found interesting applications in electrochemistry. One of these was the creation of a cheap and fully environmentally friendly cathode, developed by Milczarek and Inganäs [3]. The valuable properties of lignin and its particular structure had previously been exploited by Milczarek in the construction of electrochemical sensors and detectors, as described in [4-7]. Interesting work using lignin-based material to create an innovative, cheap battery was reported by Gnedenkov et al. [8-10]. Literature reports also indicate the possibility of using lignocellulose materials, including pure lignin, as a filler in a wide range of polymers, both in strongly polar (poly(ethylene terephthalate)_PET; poly(ethylene oxide)—PEO) [11,12] and in hydrophobic (polypropylene-PP) [13,14] polymer matrices. Studies have also been carried out using poly(vinyl chloride) [15]. The biopolymer may also serve as a potential cheap and easily available biosorbent for environmentally harmful metal ions [16-20]. As a sorbent, lignin may be obtained chiefly as a waste product of the paper industry, and subjected to chemical modification to increase the number of functional groups [21,22]. It has also been reported that lignin has multifunctional barrier properties, protecting against harmful UV radiation, as well as antibacterial properties [23]. There are also promising possibilities for the use of lignin in the pharmaceutical industry and in medicine.

Chitin is an aminopolysaccharide, built of a long polymer chain consisting of $\mathrm{N}$-acetylglucosamine units connected by $\beta-1,4$-glycoside bonds [24]. Chitin is a natural polymer, obtained chiefly from the shells of marine invertebrates, including the marine sponges [25-28]. It is friendly to the natural environment, and it exhibits high chemical stability and high reactivity, and is also non-toxic, bioactive, biodegradable and biocompatible [29]. Because of these features it is used in many areas of biomedicine and biotechnology [30,31]. One of these fields is the immobilization of enzymes [32-34]. Krajewska [35] presents a wide-ranging review of the literature concerning the use of chitin as a support for many catalytic proteins. Enzymes were immobilized by cross-linking with chitin by glutaraldehyde to reduce the viscosity of fruit and vegetable juices [36]. Outside the food industry, mention might be made of the use of enzymes immobilized on chitin via physisorption [37] or with the formation of covalent bonds [38] to detect and remove phenols. One of the most industrially useful 
groups of enzymes are the lipases, which are hydrophobic enzymes. To take full advantage of their technical and economic possibilities, they are used in a form immobilized on chitin [39]. An important factor in the widespread use of chitin as a support is the universality of the forms in which it can be used. Available morphological forms include powder, flakes, beads, nanoscale whiskers and fibers [40].

The creation of a stable material with defined properties provides the possibility of combining the undoubted advantages of both precursors, such as the aforementioned biocompatibility and non-toxicity, in the process of enzyme immobilization. The presence of multiple reactive functional groups in the structure of both materials increases their affinity to biomolecules [41]. It should be noted that the fact that the matrix is made using relatively cheap waste materials has a positive impact with regard to the economic aspects of the immobilization process [42]. The systems so produced may have potential uses in many fields where there is a need for highly pure and non-toxic catalysts.

The aim of the present study was to use a chitin-lignin material as a novel matrix for immobilization by adsorption of the lipase from Aspergillus niger. This is work of an innovative aspect, because there are no reports in the literature concerning the use of this system in enzyme immobilization. The systems produced may find uses in the transesterification and hydrolysis of a wide range of compounds, as well as in the production of biosensors. The results of the analysis confirmed the effective immobilization of the lipase on the chitin-lignin support. A detailed analysis was also made of the effect of process parameters on the properties of the resulting systems, and it was shown that lipase immobilized on the composite offers greater thermal and chemical stability than the native enzyme.

\section{Results and Discussion}

\subsection{Physicochemical Evaluation}

\subsubsection{FTIR Spectroscopy}

Figure 1 shows the FTIR spectra of the chitin-lignin material, lipase from Aspergillus niger (Figure 1a), and the products following enzyme immobilization (Figure 1b). The major bands are summarized in Table 1.
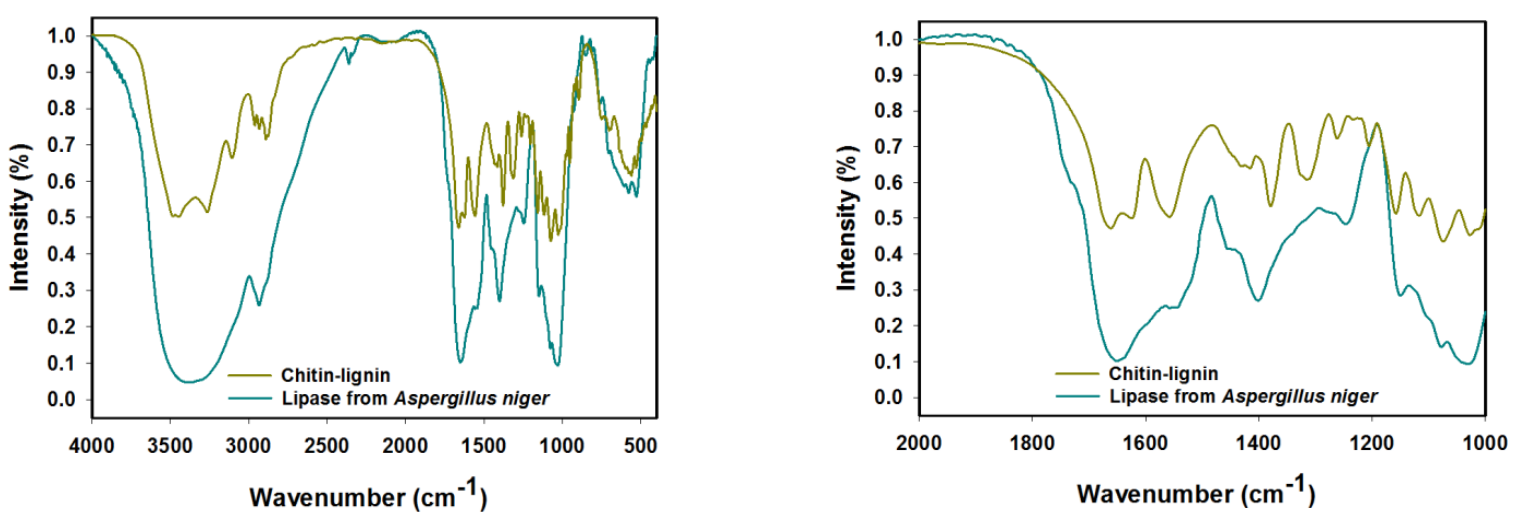

(a)

Figure 1. Cont. 

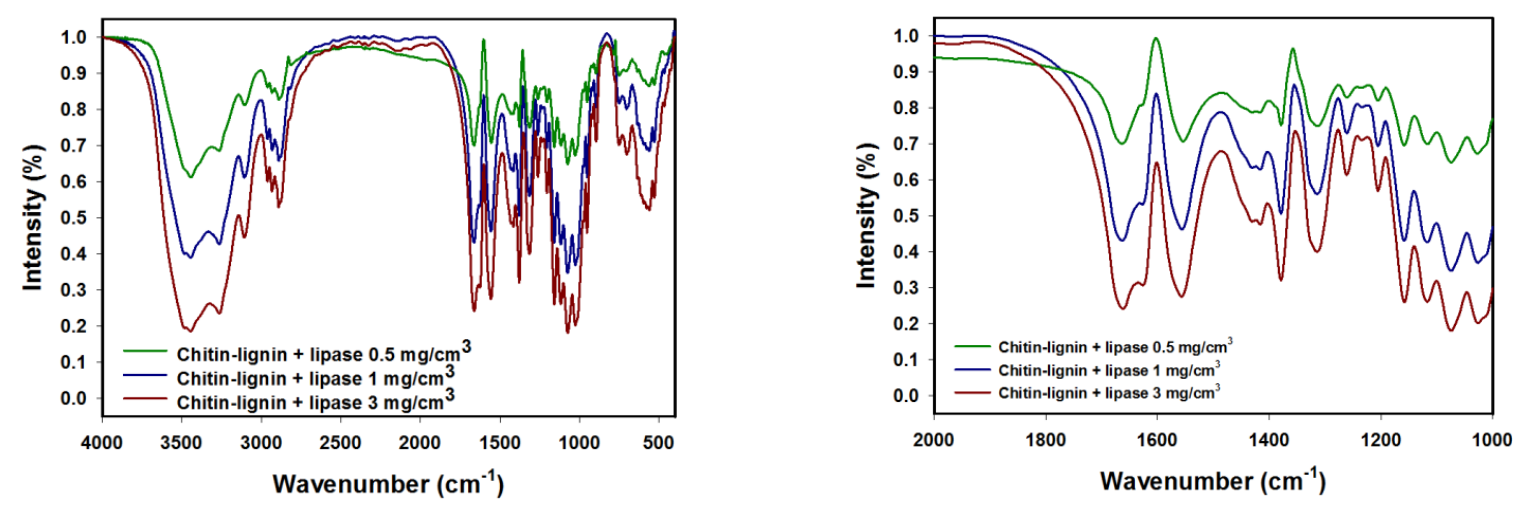

(b)

Figure 1. FTIR spectra of chitin-lignin composite and lipase (a) and selected products following $24 \mathrm{~h}$ of enzyme immobilization (b), in two different spectral range.

Table 1. Maximal vibrational wavenumbers $\left(\mathrm{cm}^{-1}\right)$ attributed to lipase from Aspergillus niger, chitin-lignin material, and products following immobilization.

\begin{tabular}{|c|c|c|c|}
\hline Lipase from Aspergillus niger & Chitin-Lignin Material & Products after Immobilization & Vibrational Assignment \\
\hline 3460 & 3444 & 3457 & O-H stretching \\
\hline 3242 & 3257 & 3264 & N-H stretching \\
\hline- & 3111 & 3112 & $\mathrm{C}_{\mathrm{Ar}}-\mathrm{H}$ stretching \\
\hline 2931 & $2965,2930,2877$ & $2966,2935,2879$ & $\mathrm{CH}_{\mathrm{x}}$ stretching \\
\hline- & 1674 & 1676 & $\mathrm{C}=\mathrm{O}$ stretching \\
\hline 1647 & 1625 & 1639 & amide I stretching \\
\hline 1546 & 1556 & 1552 & amide II bending \\
\hline 1448 & 1432 & 1438 & $\mathrm{CH}_{2}$ bending \\
\hline- & 1420 & 1417 & $\mathrm{C}_{\mathrm{Ar}}-\mathrm{C}_{\mathrm{Ar}}$ stretching \\
\hline 1402 & 1388 & 1401 & $\mathrm{O}-\mathrm{H}$ stretching \\
\hline- & 1323 & 1329 & C-O (syringyl unit) streching \\
\hline 1257 & 1268 & 1261 & amide III bending \\
\hline $1151,1073,1037$ & $1158,1116,1077,1022$ & $1162,1113,1081,1027$ & C-O-C (ring), C-O stretching \\
\hline- & 953 & 957 & $\mathrm{CH}_{3}$ bending \\
\hline- & 903 & 905 & $\beta$-1,4-glycosidic bonds \\
\hline- & 745 & 745 & aromatic $\mathrm{C}-\mathrm{H}$ (guaiacyl unit), bending \\
\hline 576 & 558 & 571 & $\mathrm{~N}-\mathrm{H}$ bending \\
\hline 531 & 527 & 530 & $\mathrm{C}-\mathrm{C}$ scissoring \\
\hline
\end{tabular}

Analysis of the FTIR spectrum of the enzyme prior to immobilization shows the presence of a band in the range $3550-3200 \mathrm{~cm}^{-1}$ associated with stretching vibrations of $\mathrm{O}-\mathrm{H}$ and $\mathrm{N}-\mathrm{H}$ groups, and one at wavenumber $2931 \mathrm{~cm}^{-1}$ from stretching vibrations of $\mathrm{C}-\mathrm{H}\left(\mathrm{CH}_{3}\right.$ and $\left.\mathrm{CH}_{2}\right)$. The most important signals in the spectrum of the native lipase are peaks at wavenumbers $1647 \mathrm{~cm}^{-1}, 1546 \mathrm{~cm}^{-1}$ and $1257 \mathrm{~cm}^{-1}$, whose presence is characteristic of stretching vibrations of amide I, II and III bonds [43,44]. The FTIR spectrum of the enzyme also features a peak at wavenumber $1402 \mathrm{~cm}^{-1}$, generated by stretching vibrations of $\mathrm{O}-\mathrm{H}$ groups, and a low-intensity signal at $1448 \mathrm{~cm}^{-1}$ confirming the presence of bending vibrations of $\mathrm{CH}_{2}$. The group of signals at $1151 \mathrm{~cm}^{-1}, 1073 \mathrm{~cm}^{-1}$ and $1037 \mathrm{~cm}^{-1}$ are associated with the presence of C-O-C bonds in the protein structure [45]. In addition, of note are two signals below 
$1000 \mathrm{~cm}^{-1}$ : at $576 \mathrm{~cm}^{-1}$ a band of $\mathrm{N}-\mathrm{H}$ stretching vibrations, and at $531 \mathrm{~cm}^{-1}$ a band of scissor vibrations of the $\mathrm{C}-\mathrm{C}$ bonds forming the skeleton of the enzyme structure [46].

Analysis of the spectrum of the chitin-lignin matrix confirms that the expected product was obtained. It also features a large number of bands, this being a result of the complex structure of the system. Attention is drawn to the bands with maxima at $3444 \mathrm{~cm}^{-1}$ and $3257 \mathrm{~cm}^{-1}$, attributed to stretching vibrations of $\mathrm{O}-\mathrm{H}$ and $\mathrm{N}-\mathrm{H}$ groups. A peak with a maximum at $3111 \mathrm{~cm}^{-1}$ is associated with stretching vibrations of $\mathrm{C}_{\mathrm{Ar}} \mathrm{H}$ groups present in the lignin structure [47]. A series of signals in the range 2970-2870 $\mathrm{cm}^{-1}$ confirms the presence of $\mathrm{CH}_{2}$ and $\mathrm{CH}_{3}$ groups in the structure of the composite, while the distinct band with a maximum at $1674 \mathrm{~cm}^{-1}$ comes from stretching vibrations of $\mathrm{C}=\mathrm{O}$ bonds. Four signals between $1160 \mathrm{~cm}^{-1}$ and $1020 \mathrm{~cm}^{-1}$ can be attributed to stretching vibrations of C-O-C bonds in the glucose ring in chitin, as well as other $\mathrm{C}-\mathrm{O}$ bonds in the material [48]. The interpretation of the carbon-oxygen bonds present in the system is supplemented by a peak at wavenumber $905 \mathrm{~cm}^{-1}$, which is a consequence of the $\beta-1,4-$ glycosidic bonds in chitin [49]. Note should also be taken of the signals originating from vibrations of amide I, II and III bonds. These are bands analogous to those present in the enzyme structure, but appearing at slightly different wavenumbers, respectively $1639 \mathrm{~cm}^{-1}, 1552 \mathrm{~cm}^{-1}$ and $1261 \mathrm{~cm}^{-1}$, as a result of the different chemical environment of the bonds. Very significant bands, confirming the production of a chitin-lignin material, are present at $1420 \mathrm{~cm}^{-1}$, $1329 \mathrm{~cm}^{-1}$ and $745 \mathrm{~cm}^{-1}$, and originate from the stretching and bending vibrations of the aromatic structures present in lignin [50].

The FTIR spectra of the systems following immobilization carried out for $24 \mathrm{~h}$ using solutions of the enzyme in various concentrations are shown in Figure 1b. Analysis of the data obtained shows that the lipase was effectively immobilized on the matrix surface. In spite of the similarity of the bands present on the spectra of the support and the enzyme, an indication is provided by the presence of signals associated with vibrations of amide I, II and III bonds contained in the protein structure, at wavenumbers $1639 \mathrm{~cm}^{-1}, 1552 \mathrm{~cm}^{-1}$ and $1261 \mathrm{~cm}^{-1}$ respectively [51]. The intensity of these bands increases, and their absorption maxima are shifted, compared with the spectrum of the support. Analogous observations apply to the signals from stretching vibrations of $\mathrm{O}-\mathrm{H}$ groups at wavenumber $3457 \mathrm{~cm}^{-1}$, and from stretching vibrations of $\mathrm{C}=\mathrm{O}$ bonds at $1676 \mathrm{~cm}^{-1}$. The changes provide additional evidence confirming the immobilization, as well as indicating hydrogen bonding between the matrix and enzyme [52]. It is also interesting that as the concentration of the enzyme solution used for immobilization increases, particular bands in the product spectra become more intense. This provides indirect evidence that there is also an increase in the quantity of the enzyme deposited on the matrix surface.

\subsection{2. ${ }^{13} \mathrm{C}$ CP MAS NMR Spectroscopy}

Figure 2 shows the ${ }^{13} \mathrm{C}$ CP MAS NMR spectra of the obtained chitin-lignin material, the native lipase, and the product following $24 \mathrm{~h}$ of immobilization of the enzyme from solution at a concentration of $3 \mathrm{mg} / \mathrm{cm}^{3}$. 


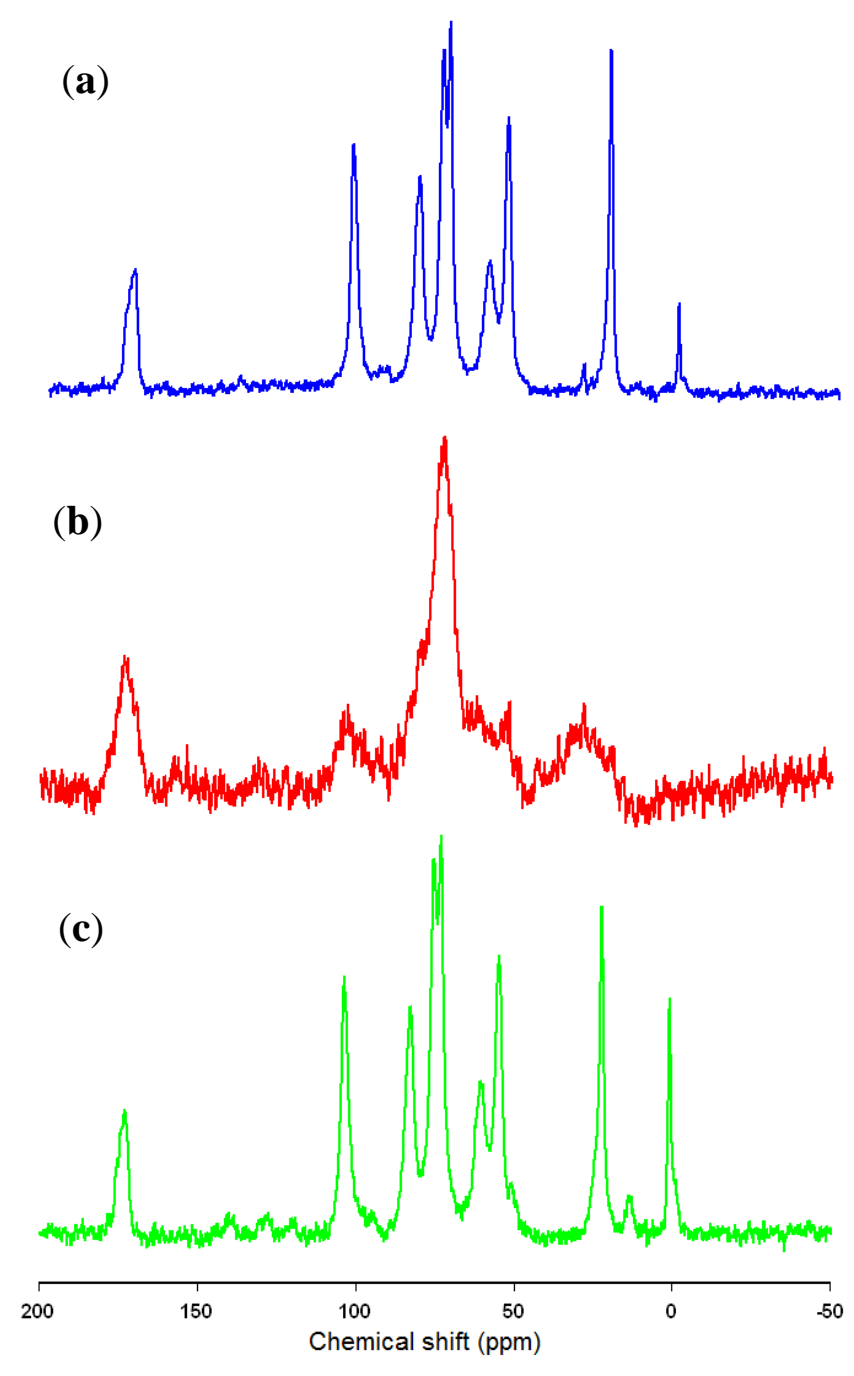

Figure 2. ${ }^{13} \mathrm{C}$ CP MAS NMR spectra of chitin-lignin (a); lipase (b) and chitin-lignin matrix with immobilized enzyme (c).

The ${ }^{13} \mathrm{C}$ CP MAS NMR spectrum of the chitin-lignin material shows the presence of signals characteristic of the precursors, which provides confirmation of the effective formation of the expected material. The signal at $22 \mathrm{ppm}$ originates from the carbon in $\mathrm{CH}_{3}$ in acetamide groups from chitin, while the entire group of peaks in the range $55-105 \mathrm{ppm}$ is generated by carbon atoms in $\mathrm{N}$-acetylglucosamine mers [53]. The distinct signal at $175 \mathrm{ppm}$ originates from the carbonyl carbons in acetamide groups in the chitin structure [54]. The spectrum of the immobilized enzyme provides confirmation of the previous findings concerning the great similarity in structure of the lipase and the chitin; which is the chief component of the composite. The spectrum of the protein contains two clear signals, with maxima at 76 and 177 ppm, as well as several bands of much smaller intensity and wider range. The spectrum of the product formed after immobilization, in view of the similarity of the spectra of the precursors, does not show many changes. There is a different shape, particularly at the base, in the signals at 56 and $107 \mathrm{ppm}$. There is also a characteristic area between 115 and $145 \mathrm{ppm}$, where there appear signals which were not observed in the spectrum of the support, but which appear with low intensity in the spectrum of the native enzyme. Analysis of the ${ }^{13} \mathrm{C} C \mathrm{CP}$ MAS NMR spectra confirms the effectiveness of the immobilization process and the immobilization of the enzyme on the 
surface of the chitin-lignin matrix. In addition, in the case of the signals on the spectrum of the system after immobilization, there is seen to be a small shift in their maxima, which may suggest that the protein is attached to the support by way of the formation of hydrogen bonds.

\subsubsection{Elemental Analysis}

Table 2 contains the results of elemental analysis, describing the change in the content of such elements as nitrogen, carbon, hydrogen and sulfur in the immobilized enzyme preparations and in the matrix used.

Table 2. Elemental content of examined elements in the chitin-lignin matrix and in products following immobilization.

\begin{tabular}{|c|c|c|c|c|c|}
\hline \multirow{2}{*}{ Enzyme Solution Concentration $\left(\mathbf{m g} / \mathrm{cm}^{3}\right)$} & \multirow{2}{*}{ Immobilization Time } & \multicolumn{4}{|c|}{ Elemental Content $(\%)$} \\
\hline & & $\mathbf{N}$ & $\mathbf{C}$ & $\mathbf{H}$ & $\mathbf{S}$ \\
\hline \multicolumn{2}{|l|}{ Chitin-lignin matrix } & 5.07 & 33.86 & 4.93 & 0.03 \\
\hline \multirow{3}{*}{0.5} & $1 \mathrm{~min}$ & 5.23 & 35.42 & 5.40 & 0.02 \\
\hline & $2 \mathrm{~h}$ & 5.58 & 37.17 & 5.67 & 0.01 \\
\hline & $24 \mathrm{~h}$ & 6.41 & 37.77 & 5.73 & 0.03 \\
\hline \multirow{3}{*}{1.0} & $1 \mathrm{~min}$ & 5.75 & 38.31 & 5.54 & 0.01 \\
\hline & $2 \mathrm{~h}$ & 5.96 & 38.77 & 5.78 & 0.03 \\
\hline & $24 \mathrm{~h}$ & 6.66 & 39.81 & 5.95 & 0.02 \\
\hline \multirow{3}{*}{3.0} & $1 \mathrm{~min}$ & 5.96 & 39.01 & 5.91 & 0.03 \\
\hline & $2 \mathrm{~h}$ & 6.03 & 39.30 & 6.05 & 0.02 \\
\hline & $24 \mathrm{~h}$ & 6.77 & 39.92 & 6.07 & 0.02 \\
\hline
\end{tabular}

The initial matrix, prior to enzyme immobilization, has a carbon content of $33.86 \%$ and a hydrogen content of $4.93 \%$. These elements are present in the structure of both lignin and chitin. Nitrogen, found in the elemental composition of the hybrid material with a content of 5.07\%, is associated with the presence of $\mathrm{N}$-acetylglucosamine groups in chitin. The presence of sulfur in the composite is explained by the use of sulfuric acid in the kraft process used to produce the lignin precursor.

The elemental analysis of systems resulting from the immobilization of lipase on the surface of the chitin-lignin matrix showed an increase in the contents of carbon, nitrogen and hydrogen, compared with the initial material. These changes are a result of the presence of those three elements in the structure of the enzyme, and confirm the effective immobilization of the protein on the surface of the support. The increase in the content of the analyzed components with higher initial concentration of protein solution and longer time of immobilization indicates that both of these parameters have a significant effect on the quantity of enzyme immobilized. The most distinct changes compared with the chitin-lignin material were observed for the system produced following a process lasting $24 \mathrm{~h}$ using a solution of concentration $3 \mathrm{mg} / \mathrm{cm}^{3}$, which may be taken as confirmation that the greatest quantity of protein was immobilized under such conditions. 


\subsubsection{XPS Analysis}

The surface composition for samples of lipase, chitin-lignin material and the product following enzyme immobilization was examined with X-ray photoelectron spectroscopy. The surface of all samples is composed of carbon, oxygen and nitrogen. Some traces of calcium, potassium and sulfur were detected, but these are not considered in the quantitative calculations. The elemental surface compositions calculated from XPS data are given in Table 3.

Table 3. Elemental composition of the surface of samples.

\begin{tabular}{cccccc}
\hline \multirow{2}{*}{ Sample Name } & \multicolumn{3}{c}{ Atomic \% } & N/C Ratio & O/C Ratio \\
\cline { 2 - 6 } & $\mathbf{C}$ & $\mathbf{O}$ & $\mathbf{N}$ & $\mathbf{H}$ & S \\
\hline Lipase & 58.2 & 30.7 & 11.1 & 0.19 & 0.53 \\
Chitin-lignin matrix & 61.4 & 32.6 & 6.0 & 0.10 & 0.53 \\
Chitin-lignin + lipase & 62.5 & 30.0 & 7.5 & 0.12 & 0.48 \\
\hline
\end{tabular}

The elemental composition of the lipase as reported by Tomizuka et al. and expressed as a C:O:N molar ratio is 61:25:14 [55]. These values are in good agreement with the ratio obtained in the present study for the surface of lipase, namely 58:31:11. Similar good agreement is obtained for the surface composition of the chitin-lignin matrix, which was reported previously [53]. The oxygen-carbon ratio close to 0.5 obtained for chitin-lignin, as well as the surface composition of the matrix, are very close to the values observed for nanocrystalline chitin [56]. Since the elemental composition of lignin differs significantly from the ratio observed here, it is concluded that the surface of the support matrix is composed mainly of chitin. The nitrogen-carbon ratio is almost twice as high for the lipase as for the chitin-lignin material. Therefore an increase in this parameter can be used as an indicator for successful enzyme immobilization, as reported previously [57]. Indeed the N/C ratio increases from 0.10 for the pure chitin-lignin matrix to 0.12 for the sample after immobilization. The elemental analysis of samples before and after immobilization, as described in Section 2.1.3., indicates an increase of approximately $20 \%$ in the nitrogen content after enzyme immobilization. This is corroborated by XPS data. This increase in nitrogen concentration following the immobilization process is taken as indirect evidence of successful lipase immobilization.

Evaluation of the chemical composition of the surface of the examined materials is based mainly on analysis of the XPS C 1s peak. The spectra have a relatively complex profile (Figure 3). Deconvolution of the experimental data was performed using a model consisting of four basic components of the $\mathrm{C} 1 \mathrm{~s}$ transition: $\mathrm{C}_{1}-\mathrm{C}_{4}$. Component $\mathrm{C}_{1}$, with a binding energy of $284.4 \pm 0.1 \mathrm{eV}$, corresponds essentially to non-functionalized carbon atoms located in the aromatic rings expected to be in the lignin structure. Component $\mathrm{C}_{2}$, with a binding energy of $284.8 \mathrm{eV}$, is attributed to all other non-functionalized $\mathrm{sp}^{2}$ and $\mathrm{sp}^{3}$ carbon atoms, bonded either to other carbon or to hydrogen atoms. Component $\mathrm{C}_{3}$, shifted by $1.4 \pm 0.2 \mathrm{eV}$ from component $\mathrm{C}_{2}$ in the direction of increasing binding energies, is attributed to a set of groups with a carbon atom bonded to one atom of oxygen or nitrogen. These include the following functional groups which are presumed to be present in the studied materials: C-O-C, C-OH, C-N-C, $\mathrm{C}-\mathrm{NH}_{2}$. Component $\mathrm{C}_{4}$, shifted by $2.9 \pm 0.2 \mathrm{eV}$ from component $\mathrm{C}_{2}$ in the direction of increasing binding energies, also corresponds to a set of functional groups: $\mathrm{C}=\mathrm{O}, \mathrm{O}-\mathrm{C}-\mathrm{O}, \mathrm{N}-\mathrm{C}-\mathrm{O}$ and $\mathrm{N}-\mathrm{C}=\mathrm{O}$. The binding energy interpretations given above are based on the energy shifts given in Appendix E [58]. A 
relative surface functional group composition obtained from decomposition of the $\mathrm{C} 1 \mathrm{~s}$ signal is given in Table 4. The total C 1 s peak intensity is taken as 100 .

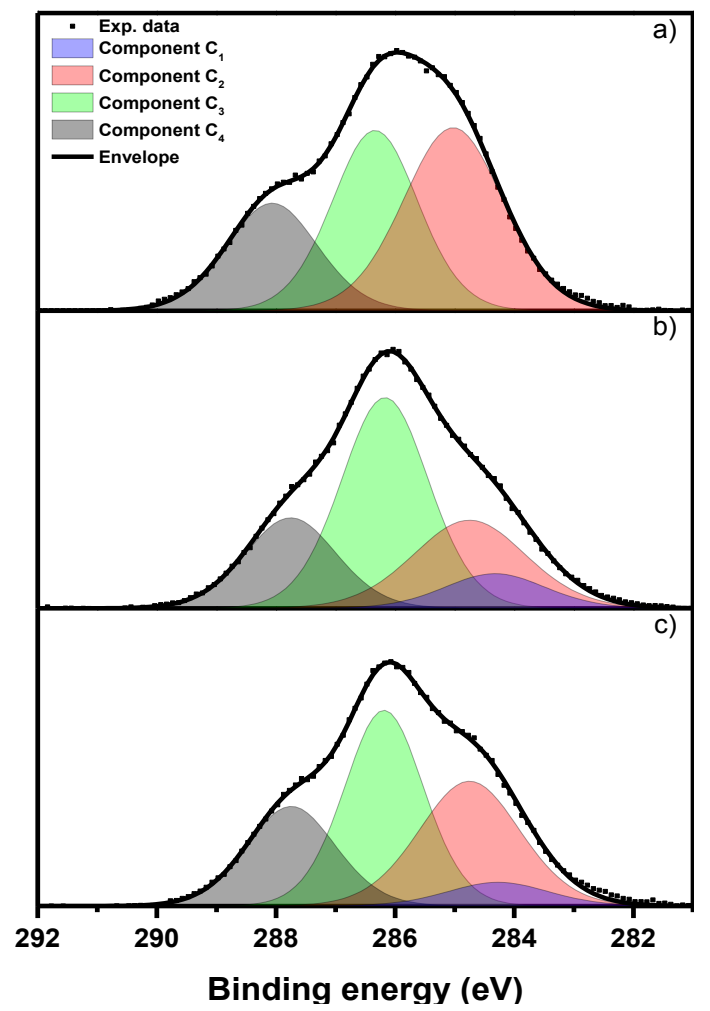

Figure 3. The XPS C 1s spectra for chitin-lignin (a); lipase (b); and the chitin-lignin + lipase product (c).

Table 4. Distribution of functional groups calculated on the basis of the deconvolution model of the XPS C 1s peak.

\begin{tabular}{ccccc}
\hline \multirow{2}{*}{ Sample Name } & \multicolumn{5}{c}{ Total C 1s Peak Intensity (\%) } \\
\cline { 2 - 5 } & $\mathbf{C}_{\boldsymbol{1}}$ & $\mathbf{C}_{\boldsymbol{2}}$ & $\mathbf{C}_{\mathbf{3}}$ & $\mathbf{C}_{\mathbf{4}}$ \\
\hline Lipase & - & 42 & 36 & 22 \\
Chitin-lignin & 9 & 25 & 46 & 20 \\
Chitin-lignin + lipase & 6 & 32 & 39 & 23 \\
\hline
\end{tabular}

Since lipase contains a relatively small number of aromatic rings, originating from amino acids such as phenylalanine or tyrosine [55], the component $C_{1}$ is not considered in the deconvolution of the $C 1 \mathrm{~s}$ spectrum for that substance. Component $\mathrm{C}_{2}$ prevails in the XPS signal, followed by $\mathrm{C}_{3}$. The support material is a mixture of chitin and lignin. The expected component ratio for pure chitin is $\mathrm{C}_{2}: \mathrm{C}_{3}: \mathrm{C}_{4}=25: 50: 25$ [59], while the ratio $\left(\mathrm{C}_{1}+\mathrm{C}_{2}\right): \mathrm{C}_{3}: \mathrm{C}_{4}$ observed for lignin is 65:29:3 [60]. On the surface of the chitin-lignin matrix observed here, the contributions of components $\mathrm{C}_{1}$ and $\mathrm{C}_{2}$ are lower than would be given by a simple average for the mixture of chitin and lignin. Therefore, as suggested earlier, it is concluded that chitin prevails on the surface of the support. Comparison of the spectra of the chitin-lignin material and the product following enzyme immobilization indicates that $\mathrm{C}_{1}$ diminishes slightly, while $\mathrm{C}_{2}$ increases. Since $\mathrm{C}_{2}$ is dominant in the XPS spectrum of lipase, we believe this to be an indication of successful enzyme immobilization. 
Some additional evidence of the successful immobilization of lipase on the chitin-lignin matrix can be observed in the XPS O 1s spectra shown in Figure 4. The XPS O 1s transition observed for lipase is symmetric, with a maximum at binding energy $531.8 \mathrm{eV}$ (dotted curve). In the case of the chitin-lignin matrix and the product of enzyme immobilization, the maximum of the $\mathrm{O} 1 \mathrm{~s}$ peak is shifted in the direction of high binding energy to $532.4 \mathrm{eV}$. The structure of both chitin and lignin is dominated by $\mathrm{C}-\mathrm{OH}$ groups, while in the case of the lipase a more equal ratio between hydroxyl and carboxyl groups is expected. The characteristic position of the $\mathrm{O} 1 \mathrm{~s}$ peak for $\mathrm{C}-\mathrm{OH}$ groups is approximately $532.5 \mathrm{eV}$, while its position for $\mathrm{C}=\mathrm{O}$ groups is reported to be about $531.3 \mathrm{eV}$ [61]. Accordingly, a shift in the XPS O 1s spectra is observed between the lipase and chitin-lignin. A small difference is also observed between the profile of the $\mathrm{O} 1 \mathrm{~s}$ peak for chitin-lignin and for the chitin-lignin + lipase product. On the high-energy side of the spectrum the intensity of the $\mathrm{O} 1 \mathrm{~s}$ peak obtained for the product following enzyme immobilization is slightly higher than the intensity of the peak obtained for the chitin-lignin support. The difference is small, but considering the relatively low quantity of immobilized lipase, it can be taken as confirmation of the increased concentration of $\mathrm{C}=\mathrm{O}$ groups, which is an expected result of lipase being attached to the support.

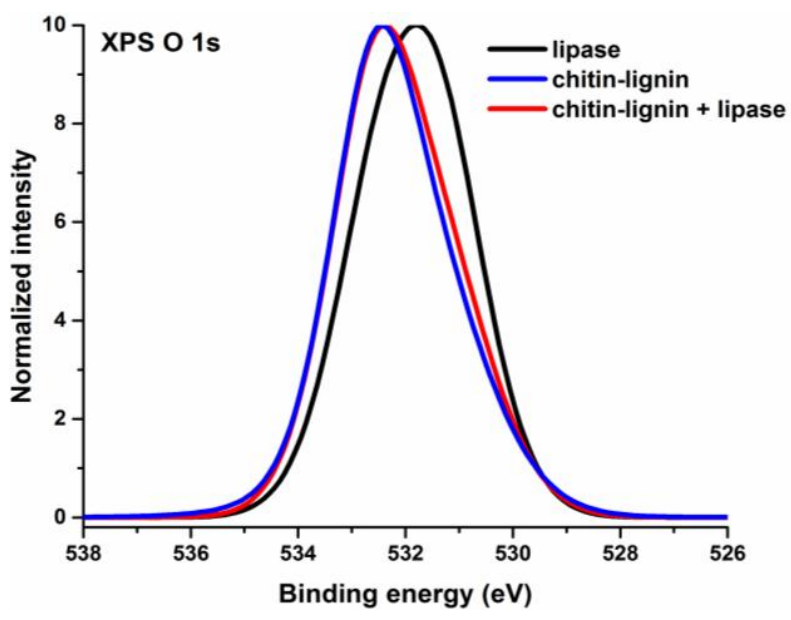

Figure 4. XPS O 1s spectra for lipase, chitin-lignin matrix and the product following enzyme immobilization.

XPS analysis provides no direct confirmation of lipase immobilization, since there is no apparent evidence of the formation of a new chemical environment. However, the formation of hydrogen bonds is not excluded. Moreover, the increase in the nitrogen-carbon ratio in combination with the subtle changes in the $\mathrm{C} 1 \mathrm{~s}$ and $\mathrm{O} 1 \mathrm{~s}$ component ratios can be considered an indication of successful immobilization of the enzyme.

\subsubsection{Electrokinetic Characteristic}

Studies of zeta potential and the effect of $\mathrm{pH}$ provide very valuable data about the electrokinetic properties of dispersed systems. Figure 5 shows the results obtained. Determination of the zeta potential of the biocomposite with and without immobilized enzyme provides indirect confirmation of the effectiveness of the suggested method of immobilization. The graph shows the values of the zeta potential obtained for selected samples following immobilization for $24 \mathrm{~h}$. 
The zeta potential of the chitin-lignin system is negative over the whole of the investigated $\mathrm{pH}$ range, and the isoelectric point is not attained. This results from the presence of specific functional groups (- $\mathrm{COOH}$ and $-\mathrm{OH})$ on the surface of the component biopolymers. The electrokinetic potential of pure kraft lignin is even more negative; its value increased when the lignin was combined with chitin (due to the presence of surface $\mathrm{NH}_{2}$ functional groups, which in an acidic environment can undergo protonation to $\mathrm{NH}_{3}{ }^{+}$) [53]. Lipase consists of several amino acids. The high percentage of acidic amino acids (Asp and Glu) gives the molecule a net negative charge, which is higher than the total for the positively charged residues (Arg, Lys, and His) [62]. That is why the isoelectric point of this protein is about $4[63,64]$. This value indicates that only at $\mathrm{pH}$ values below it will the surface charge (and indirectly zeta potential) be positive. The absolute value of zeta potential of chitin-lignin + lipase is smaller than this for matrix, especially in acidic condition, which can be explained by adsorption of lipase.

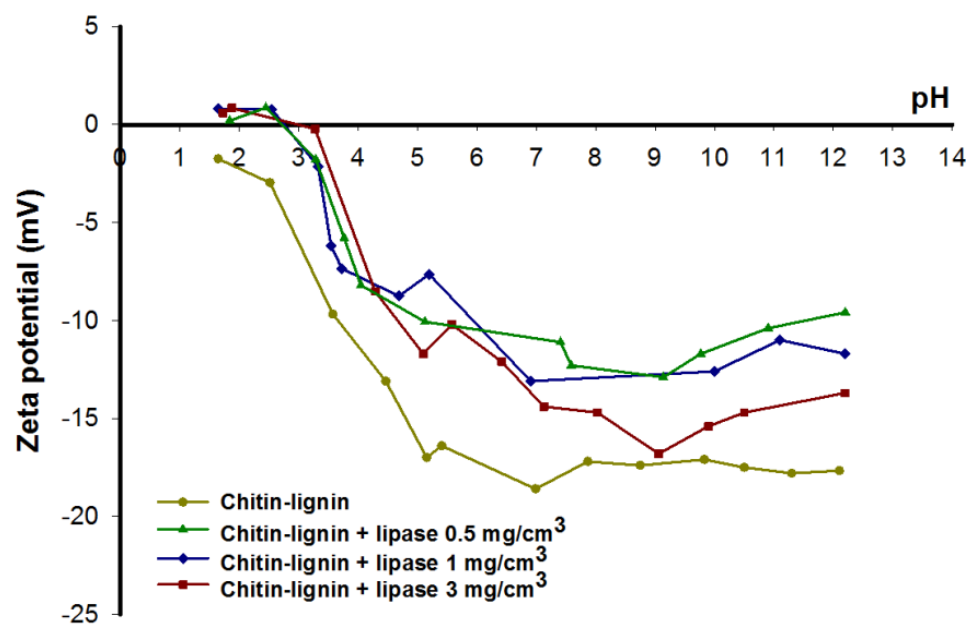

Figure 5. The zeta potential, as a function of $\mathrm{pH}$, of the chitin-lignin material and selected products following immobilization.

Following immobilization of the enzyme on the surface of the support, as a result of interactions between the surface groups of the support and of the enzyme, the absolute values of the zeta potential decreased. This provides indirect evidence of the adsorptive nature of the attachment of the enzyme to the chitin-lignin support [65-67]. There was a decrease in the number of the free functional groups which are responsible for generating the charge. In addition, the chitin-lignin products upon addition of enzyme attain their isoelectric point (the $\mathrm{pH}$ at which the zeta potential is zero), which had previously not been observed. From the measured values of zeta potential it can be concluded that the quantity of immobilized enzyme influences its electrokinetic properties [68]. Nevertheless, irrespective of the quantity of adsorbed enzyme, the value of the isoelectric point is 2.7 .

\subsubsection{Quantity of Immobilized Enzyme}

Based on the Bradford method [69] it was determined how the quantity of enzyme immobilized on the surface of the chitin-lignin support is affected by the concentration of the solution used in the immobilization process, and by the duration of the process. Table 5 contains detailed data on the quantity of biocatalyst adsorbed, depending on the concentration of the protein solution and the time of the process. The results are presented in terms of milligrams of enzyme per 1 gram of used matrix. 
The results show that increasing the time of the immobilization process causes greater quantities of enzyme to be adsorbed. It should nonetheless be noted that the greatest increase in adsorbed protein occurs in the initial stages of the process. After the process time exceeds $4 \mathrm{~h}$, the quantity of immobilized biocatalyst does not increase significantly, and the maximum change, depending on the concentration of the enzyme solution, is approximately $2 \mathrm{mg} / \mathrm{g}$.

Table 5. Content of investigated elements in the chitin-lignin matrix and in the products following immobilization.

\begin{tabular}{|c|c|c|c|}
\hline \multirow{3}{*}{ Immobilization Time } & \multicolumn{3}{|c|}{ Concentration of Enzyme Solution $\left(\mathrm{mg} / \mathrm{cm}^{3}\right)$} \\
\hline & 0.5 & 1 & 3 \\
\hline & \multicolumn{3}{|c|}{ Amount of Immobilized Enzyme (mg/g) } \\
\hline $1 \mathrm{~min}$ & 1.45 & 5.13 & 6.19 \\
\hline $1 \mathbf{h}$ & 6.23 & 9.76 & 14.97 \\
\hline $2 \mathrm{~h}$ & 8.17 & 10.84 & 18.46 \\
\hline $4 \mathrm{~h}$ & 8.58 & 11.37 & 18.72 \\
\hline $24 \mathrm{~h}$ & 9.22 & 11.84 & 19.31 \\
\hline $96 \mathrm{~h}$ & 9.94 & 12.57 & 20.28 \\
\hline
\end{tabular}

Another parameter having a significant effect on the quantity of protein in the products following immobilization is the concentration of the solution used. The results show that the greatest quantity of protein is adsorbed from the solution with a concentration of $3 \mathrm{mg} / \mathrm{cm}^{3}$. When identical times of immobilization are compared, this solution enables the adsorption of more than twice as much protein as when a solution of concentration $0.5 \mathrm{mg} / \mathrm{cm}^{3}$ is used.

The greatest quantity of the enzyme was adsorbed from the solution with a concentration of $3 \mathrm{mg} / \mathrm{cm}^{3}$ following a process lasting $96 \mathrm{~h}$. However, the optimum time of the immobilization process is $4 \mathrm{~h}$, enabling comparable quantities of protein to be immobilized in a much shorter time, which has a positive impact on the economics of the studied process.

\subsection{Hydrolytic Activity}

\subsubsection{Determination of Hydrolytic Activity}

The hydrolytic activity of the free and immobilized enzyme was assessed spectrophotometrically based on the hydrolysis reaction of para-nitrophenyl palmitate. Figure 6 shows the results for catalytic activity of preparations with immobilized lipase obtained using enzyme solutions with concentrations of $0.5,1$ and $3 \mathrm{mg} / \mathrm{cm}^{3}$, subjected to immobilization over different time intervals. The measurements were performed at $30^{\circ} \mathrm{C}$.

The systems with immobilized enzymes have lower catalytic activity than the native lipase, for which the activity is measured at $7.46 \mathrm{mU}$. Irrespective of the concentration of the protein solution, the greatest activity is found for the products formed after $4 \mathrm{~h}$ of immobilization. The results showed the enzyme solution with a concentration of $3 \mathrm{mg} / \mathrm{cm}^{3}$ to be optimum for immobilization on a chitin-lignin support. The resulting immobilized lipase has the highest activity of all of the systems investigated, equal to $5.76 \mathrm{mU}$. This sample was selected for further analysis to determine the stability of the resulting system depending on the conditions of the catalyzed reaction. 
The results show unambiguously that a greater quantity of immobilized enzyme does not lead directly to an increase in the system's catalytic activity. The products obtained following $96 \mathrm{~h}$ of immobilization, which have the greatest quantities of immobilized protein, exhibit a lower activity. This is caused by the accumulation of too great a quantity of the enzyme on the matrix surface, blocking the active sites on the biocatalyst and thus reducing its activity [70].

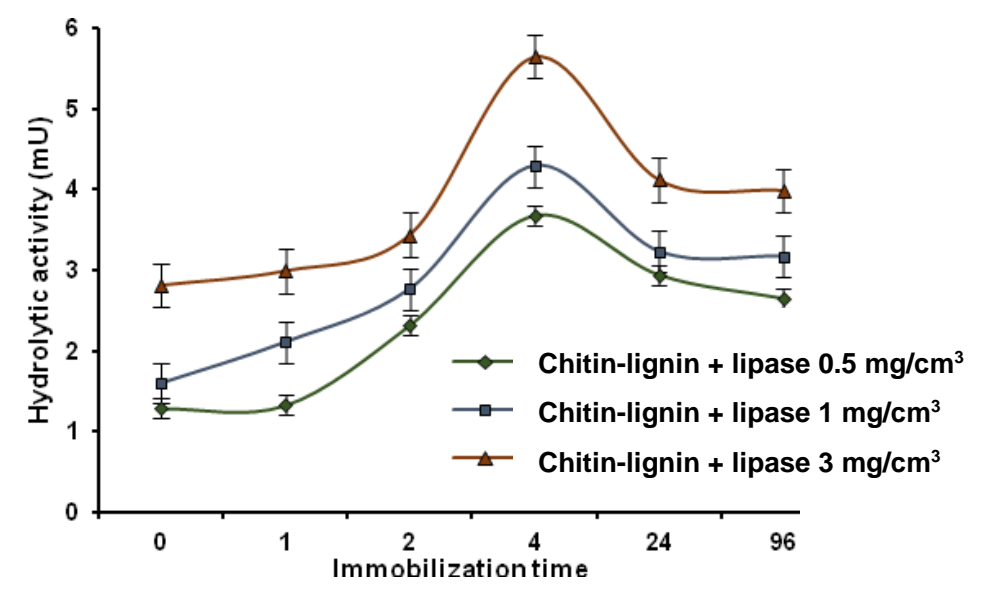

Figure 6. Graph showing changes in the catalytic activity of products depending on the time of immobilization and the concentration of the enzyme solution.

\subsubsection{Thermal Stability}

Thermal stability is one of the most important properties of immobilized enzymes. The thermal stability of the immobilized lipase was studied, in comparison with the native enzyme, over a temperature range of $10-80{ }^{\circ} \mathrm{C}$. For this analysis, the system selected was one that underwent $4 \mathrm{~h}$ immobilization in the enzyme solution at a concentration of $3 \mathrm{mg} / \mathrm{cm}^{3}$ in phosphate buffer at $\mathrm{pH}=7$. Figure 7 shows a comparison of the thermal stability of the native lipase with that of the lipase immobilized on a chitin-lignin matrix.

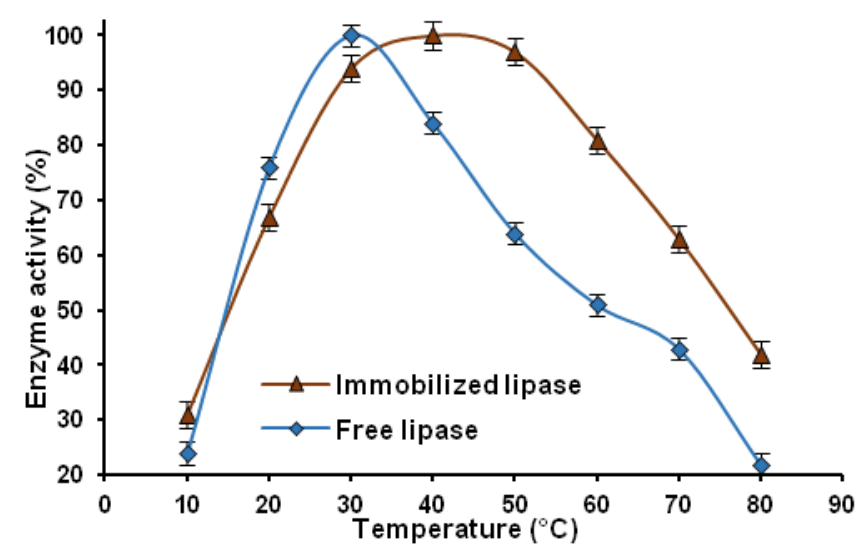

Figure 7. Graph of thermal stability of immobilized and native lipase in the temperature range $10-80{ }^{\circ} \mathrm{C}$. 
The native lipase attains its maximum hydrolytic activity at $30{ }^{\circ} \mathrm{C}$, while that of the immobilized enzyme occurs at $40{ }^{\circ} \mathrm{C}$. It should be noted, however, that the immobilized lipase retains more than $90 \%$ of its initial activity even at $50{ }^{\circ} \mathrm{C}$, where the properties of the free enzyme are lost to a significant degree. These results show clearly that attaching the biocatalyst to a solid support has a positive effect on its resistance to denaturation at high temperature. This has been shown to be a result of an increase in the rigidity of the protein structure [71]. The thermal stability increased because the immobilization process could protect the tertiary structure of the peptide from conformational changes caused by the higher temperature [72].

\subsection{3. $\mathrm{pH}$ Stability}

The $\mathrm{pH}$ stability is an important characteristic of systems resulting from immobilization. The $\mathrm{pH}$ stability of the immobilized lipase, compared with that of the native enzyme, was studied over a $\mathrm{pH}$ range of 3 to 11 at $30{ }^{\circ} \mathrm{C}$. Figure 8 shows a comparison of the $\mathrm{pH}$ stability of the native lipase with that of the lipase immobilized on a chitin-lignin matrix.

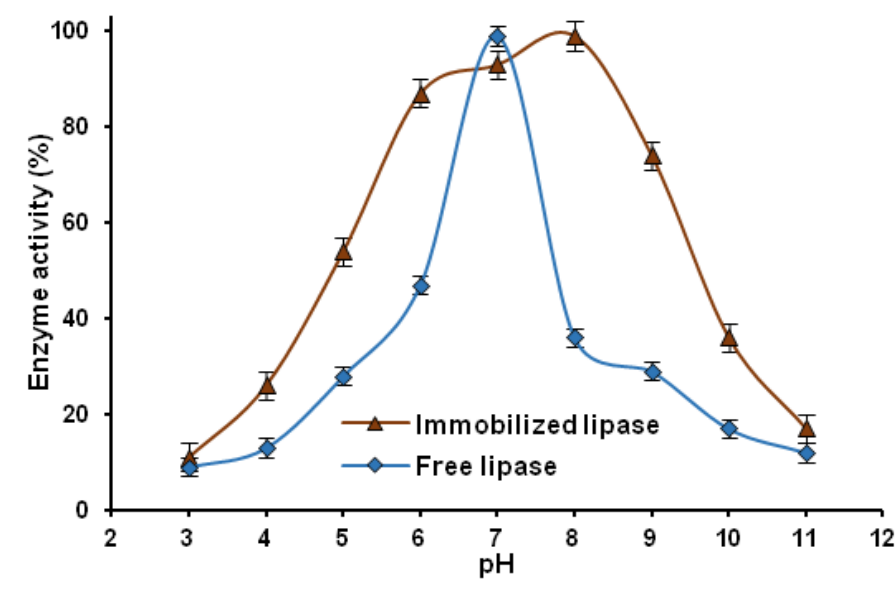

Figure 8. Graph showing changes in the catalytic active of immobilized and native lipase over the $\mathrm{pH}$ range $3-11$.

The data above show that the $\mathrm{pH}$ has a large effect on the activity of the lipase in an aqueous environment. The activity of native lipase reaches a maximum at $\mathrm{pH}=7$, and small changes in $\mathrm{pH}$ cause a large decrease in hydrolytic activity, by as much as $50 \%$. The immobilized lipase has its highest activity at $\mathrm{pH}=8$, which is characteristic of immobilized enzymes in this catalytic group [73]. The attachment of the enzyme to a solid support also causes it to retain more than $70 \%$ of its activity in the $\mathrm{pH}$ range 6-9. The improved stability of the immobilized enzyme compared with the native protein is probably a result of conformational changes taking place in the protein tertiary and quaternary structure following immobilization [74]. An increase in $\mathrm{pH}$ stability of the immobilized lipase is also connected with the changes in spatial orientation of secondary structure of the protein backbone, caused by the formation of hydrogen bonds between the enzyme and matrix [75]. 


\subsubsection{Reusability}

Figure 9 shows the reusability of the lipase immobilized on the chitin-lignin matrix over 20 cycles. In each cycle, the immobilized lipase was separated and washed with phosphate buffer, and the activity was calculated for p-NPP hydrolysis.

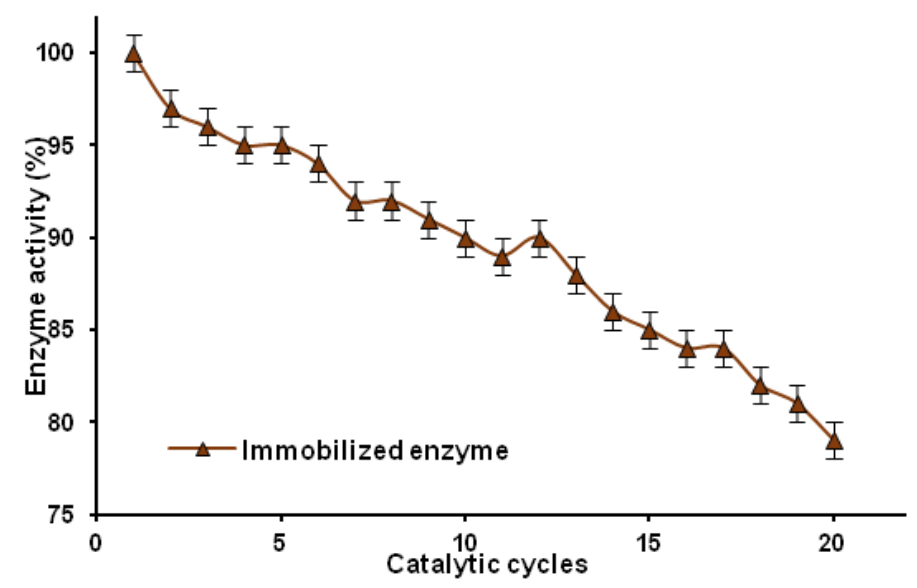

Figure 9. Changes in catalytic activity of immobilized lipase over 20 catalytic cycles.

The immobilized lipase was tested over 20 catalytic cycles, and was found to retain approximately $80 \%$ of its initial activity. The high reusability of products based on a chitin-lignin matrix may also lead to widespread use of this support in the immobilization of enzymes of other catalytic groups. Prolongation of the catalytic activity of these products may also lead to a significant reduction in the costs of carrying out reactions in real-life applications.

\section{Experimental Section}

\subsection{Materials}

The precursors, $\alpha$-chitin powder from crab shells (technical grade) and kraft lignin (reagent grade), and $15 \%$ hydrogen peroxide as an oxidizing agent, were obtained from Sigma-Aldrich (Munich, Germany). Immobilization was carried out using commercial lipase from Aspergillus niger (Sigma-Aldrich, Munich, Germany) and phosphate buffer at $\mathrm{pH}=7$ (Amresco, Solon, OH, USA). The 85\% phosphoric acid and 96\% ethyl alcohol used in the Bradford method were obtained from Chempur (Piekary Śląskie, Poland). Coomassie Brilliant Blue G-250 (CBB G-250) was obtained from Sigma-Aldrich (Munich, Germany). The catalytic activity tests used para-nitrophenyl palmitate, Triton X-100 and gum arabic from Sigma-Aldrich (Munich, Germany) and 2-propanol from Chempur (Piekary Śląskie, Poland).

\subsection{Preparation of Chitin-Lignin Material}

The process of obtaining the chitin-lignin material (precursors ratio $1: 1, \mathrm{~m} / \mathrm{m}$ ) began with the addition of $15 \mathrm{~cm}^{3}$ of $15 \%$ hydrogen peroxide to the lignin, according to the procedure reported in previously published work [53]. The mixture was subjected to intensive mixing at approximately 
$800 \mathrm{rpm}$ for about $30 \mathrm{~min}$ using a high-speed stirrer (Eurostar Digital, IKA Werke GmbH, Staufen, Germany). Chitin was then added to the reactor, and mixing continued for $60 \mathrm{~min}$. The resulting chitin-lignin material was filtered under reduced pressure and washed with distilled water. The product was then dried in a convectional dryer (Memmert, Munich, Germany) at approximately $105{ }^{\circ} \mathrm{C}$ for about $24 \mathrm{~h}$.

\subsection{Enzyme Immobilization}

The process of immobilization of lipase from Aspergillus niger on the surface of the chitin-lignin composite was carried out using solutions of the enzyme at concentrations of $0.5,1$ and $3 \mathrm{mg} / \mathrm{cm}^{3}$ in a phosphate buffer at $\mathrm{pH}=7$, for times of $1 \mathrm{~min}$ and 1, 2, 4, 24 and $96 \mathrm{~h}$. Quantities of $250 \mathrm{mg}$ of the previously obtained matrix were placed in conical flasks, and $15 \mathrm{~cm}^{3}$ of the solution of the enzyme in the required concentration was added. The mixture was placed in a KS260 BASIC shaker (IKA Werke $\mathrm{GmbH}$, Staufen, Germany), and shaken for the required length of time. Afterwards the precipitate was filtered under reduced pressure and left to dry at room temperature for $24 \mathrm{~h}$.

\subsection{Physicochemical Evaluation}

The presence of the expected functional groups was confirmed by Fourier transform infrared (FTIR) spectroscopy, using a Vertex 70 spectrophotometer (Bruker, Karlsruhe, Germany). The materials were analyzed in the form of tablets, made by placing a mixture of anhydrous $\mathrm{KBr}$ (ca. $0.25 \mathrm{~g}$ ) and $1.5 \mathrm{mg}$ of the tested substance in a steel ring under a pressure of $10 \mathrm{MPa}$. The tests were performed at a resolution of $0.5 \mathrm{~cm}^{-1}$ in the wavenumber range $4000-400 \mathrm{~cm}^{-1}$.

${ }^{13} \mathrm{C}$ CP MAS NMR measurement was carried out on a DSX spectrometer (Bruker, Karlsruhe, Germany). For the determination of NMR spectra, a sample of approximately $100 \mathrm{mg}$ was placed in a $\mathrm{ZrO}_{2}$ rotator with diameter $4 \mathrm{~mm}$, which enabled spinning of the sample. Centrifugation at the magic angle was performed at a spinning frequency of $8 \mathrm{kHz}$. The ${ }^{13} \mathrm{C} \mathrm{CP}$ MAS NMR spectra were recorded at $100.63 \mathrm{MHz}$ in a standard $4 \mathrm{~mm}$ MAS probe using single pulse excitation with high power proton decoupling (pulse repetition $10 \mathrm{~s}$, spinning speed $8 \mathrm{kHz}$ ).

The elemental contents of the chitin-lignin hybrid material and the immobilized enzyme were determined using a Vario EL Cube instrument (Elementar Analysensysteme GmbH, Hanau, Germany), which is capable of registering the percentage content of carbon, hydrogen, nitrogen and sulfur in samples after high-temperature combustion. A properly weighed sample was placed in an 80-position autosampler and subjected to combustion. The decomposed sample was transferred in a stream of inert gas into an adsorption column. The results are given to $\pm 0.01 \%$, and each is obtained by averaging three measurements.

The X-ray photoelectron spectra were obtained using $\mathrm{Al} K \alpha(\mathrm{h} v=1486.6 \mathrm{eV})$ radiation with a Prevac system equipped with a Scienta SES 2002 (VG Scienta, Uppsala, Sweden) electron energy analyzer operating at constant transmission energy $\left(E_{p}=50 \mathrm{eV}\right)$. The spectrometer was calibrated using the following photoemission lines (with reference to the Fermi level): $\mathrm{EB} \mathrm{Cu} \mathrm{2p3/2}=932.8 \mathrm{eV}, \mathrm{EB} \mathrm{Ag}$ $3 \mathrm{~d}_{5 / 2}=368.3 \mathrm{eV}, \mathrm{EB} \mathrm{Au} 4 \mathrm{f}_{7 / 2}=84.0 \mathrm{eV}$. The instrumental resolution, as evaluated by the full width at half maximum (FWHM) of the $\mathrm{Ag} 3 \mathrm{~d}_{5 / 2}$ peak, was $1.0 \mathrm{eV}$. The samples were placed loose in a grooved molybdenum sample holder. The analysis chamber was evacuated during the experiments to better 
than $1 \cdot 10^{-9}$ mbar. Data processing involved background subtraction by means of an "S-type" integral profile and a curve-fitting procedure (a mixed Gaussian-Lorentzian function was employed) based on a least-squares method (CasaXPS software). The experimental errors were estimated to be $\pm 0.1 \mathrm{eV}$ for the photoelectron peaks of carbon and oxygen. Charging effects were corrected using the $\mathrm{C}$ 1s component attributed after deconvolution to aliphatic carbon bonds (component $\mathrm{C}_{2}$ ) and determined at $284.8 \mathrm{eV}$. The reproducibility of the peak position thus obtained was $\pm 0.1 \mathrm{eV}$. The surface composition of the samples was obtained on the basis of the peak area intensities of the $\mathrm{C} 1 \mathrm{~s}, \mathrm{O} 1 \mathrm{~s}$, and $\mathrm{N} 1 \mathrm{~s}$ transitions using the sensitivity factor approach and assuming homogeneous distribution of elements in the surface layer.

The electrokinetic stability of the materials with immobilized enzyme was determined on the basis of zeta potential dependence on $\mathrm{pH}$, using a Zetasizer Nano ZS (Malvern Instruments Ltd., Worcestershire, UK) equipped with an autotitrator. Measurements were made in a $0.001 \mathrm{M} \mathrm{NaCl}$ solution over the $\mathrm{pH}$ range $2-12$, using $0.001 \mathrm{M} \mathrm{NaCl}$ solution.

The quantity of immobilized enzyme was determined by the Bradford method [69]. A solution of the Bradford reagent was prepared by dissolving $10 \mathrm{mg}$ of Coomassie Brilliant Blue G-250 in $5 \mathrm{~cm}^{3}$ of $96 \%$ ethyl alcohol, $15 \mathrm{~cm}^{3}$ of $85 \%$ phosphoric acid and $80 \mathrm{~cm}^{3}$ of water. In a quartz cuvette, $4 \mathrm{~cm}^{3}$ of the Bradford reagent was mixed with $800 \mu \mathrm{L}$ of the analyzed protein solution and $100 \mu \mathrm{L}$ water, and the analysis was performed $10 \mathrm{~min}$ after the preparation of the mixture. Measurements were made at wavelength $595 \mathrm{~nm}$, using a JASCO 650 spectrophotometer (Jasco, Tokyo, Japan).

\subsection{Evaluation of Hydrolytic Activity}

The activity of the immobilized lipase was measured by the method used in our previous work [76], with slight modifications. Spectrophotometric measurements were made for $2 \mathrm{~min}$ at wavelength $410 \mathrm{~nm}$ at $30{ }^{\circ} \mathrm{C}$, based on the transesterification reaction of para-nitrophenyl palmitate (p-NPP) to para-nitrophenyl (p-NP). Hydrolytic activity was measured in $1 \mathrm{~cm}^{3}$ quartz cuvettes containing $5 \mathrm{mg}$ of immobilized lipase with $2.7 \mathrm{~cm}^{3}$ of substrate solution containing $10 \mathrm{mM}$ phosphate buffer, $10 \mathrm{mM}$ of p-NPP solution in 2-propanol, $0.44 \%$ mass fraction of Triton X-100 and 0.11\% mass fraction of gum arabic. One mUnit of immobilized enzyme activity was defined as the release of $1 \mu \mathrm{moL}$ of $\mathrm{p}-\mathrm{NP}$ per minute.

\subsubsection{Thermal Stability}

The thermal stability of the immobilized and native lipase was determined over a temperature range of $10-80^{\circ} \mathrm{C}$. Hydrolytic activity was calculated as described in Section 3.5.

\subsection{2. $\mathrm{pH}$ Stability}

The $\mathrm{pH}$ stability of the immobilized and native lipase was determined by incubating the substrate solution at different $\mathrm{pH}$ values $(3,5,7,9,11)$ to compare the activity of the free and immobilized lipase. Catalytic activity was calculated as described in Section 3.5. 


\subsubsection{Reusability}

The reusability of the immobilized lipase was determined by testing over 20 cycles. Between each reaction step, the chitin-lignin matrix with the immobilized enzyme was separated from the substrate solution by centrifugation and washed with phosphate buffer. The hydrolytic activity was calculated as described in Section 3.5.

\section{Conclusions}

In this study, a chitin-lignin system was used as an innovative matrix in the process of immobilizing lipase from Aspergillus niger. Detailed characteristics of the obtained matrix, and confirmation of the effective immobilization of the enzyme, were obtained using such techniques as FTIR, XPS, ${ }^{13} \mathrm{C} \mathrm{CP}$ MAS NMR and elemental analysis. It was shown that both the time of the process and the initial concentration of the protein solution have a significant effect on the properties of the products obtained. A determination was also made of the quantity of enzyme immobilized on the surface of the system, and of the catalytic activity of the system following lipase immobilization. It was found that the immobilized lipase exhibits lower activity than the free enzyme, but retains its catalytic properties for a greater number of reaction cycles. The enzyme bound to the chitin-lignin matrix also has greater thermal and chemical stability than the native protein. Measurement of the zeta potential enabled determination of the electrokinetic properties of the systems obtained. Detailed analysis of the FTIR spectra of the products of the immobilization process, and changes in the zeta potential and shifts in signal maxima on ${ }^{13} \mathrm{C}$ CP MAS NMR spectra, indicate that the enzyme is attached by way of physical adsorption, probably through the formation of hydrogen bonds.

\section{Acknowledgments}

The study was financed within the Polish National Center of Science funds according to decision No. DEC-2013/09/B/ST8/00159.

\section{Author Contributions}

J.Z.: Planning studies. Preparation of functional chitin-lignin biosorbent. Evaluation of enzyme immobilization efficiency. Results development. Ł.K.: Analysis of physicochemical properties of the materials obtained. Results development. M.W.: Analysis of structural properties of the materials obtained. Results development. D.M.: Implementation and description of the XPS analysis. M.N.: Implementation and description of the zeta potential analysis. A.K.-R.: Evaluation of enzyme immobilization efficiency. Results development. H.E.: Supervising manuscript with data interpretation. H.M.: Supervising manuscript with data interpretation. A.L.S.: Supervising manuscript with data interpretation. T.J.: Coordination of all tasks in the paper. Planning studies. Results development.

\section{Conflicts of Interest}

The authors declare no conflict of interest. 


\section{References}

1. Evstigneyev, E.; Shevchenko, S.; Mayorova, H.; Platonow, A. Polarographically active structural fragments of lignin. II. Dimeric model compounds and lignins. J. Wood Chem. Technol. 2004, 24, 263-278.

2. Lund, H.; Baizer, M.M. Organic Electrochemistry-An Introduction and Guide; Marcel Dekker: New York, NY, USA, 1991.

3. Milczarek, G.; Inganäs, O. Renewable cathode materials from biopolymer/conjugated polymer interpenetrating networks. Science 2012, 335, 1468-1471.

4. Milczarek, G. Preparation and characterization of a lignin modified electrode. Electroanalsia 2007, 19, 1411-1414.

5. Milczarek, G. Preparation, characterization and electrocatalytic properties of an iodine/lignin modified gold electrode. Electrochim. Acta 2009, 54, 3199-3205.

6. Milczarek, G. Lignosulfonate-modified electrodes: Electrochemical properties and electrocatalysis of NADH oxidation. Langmuir 2009, 25, 10345-10353.

7. Milczarek, G.; Rębiś, T. Synthesis and electroanalytical performance of a composite material based on poly(3,4-ethylenedioxythiophene) doped with lignosulfonate. Int. J. Electrochem. 2012, 130980, 1-7.

8. Gnedenkov, S.V.; Opra, D.P.; Sinebryukhov, S.L.; Tsvetnikov, A.K.; Ustinov, A.Y.; Sergienko, V.I. Hydrolysis lignin-based organic electrode material for primary lithium batteries. J. Solid State Electrochem. 2014, 17, 2611-2621.

9. Gnedenkov, S.V.; Opra, D.P.; Sinebryukhov, S.L.; Tsvetnikov, A.K.; Ustinov, A.Y.; Sergienko, V.I. Hydrolysis lignin: Electrochemical properties of the organic cathode material for primary lithium battery. J. Ind. Eng. Chem. 2014, 20, 903-910.

10. Opra, D.P.; Gnedenkov, S.V.; Sinebryukhov, S.L.; Tsvetnikov, A.K.; Sergienko, V.I. Fabrication of battery cathode material based on hydrolytic lignin. Solid State Phenom. 2014, 213, 154-159.

11. Kadla, J.F.; Kubo, S. Lignin-based polymer blends: Analysis of intermolecular interactions in lignin-synthetic polymer blends. Compos. A Appl. Sci. manuf. 2004, 35, 395-400.

12. Canetti, M.; Bertini, F. Supermolecular structure and thermal properties of poly(ethylene terephthalate)/lignin composites. Compos. Sci. Technol. 2007, 67, 3151-3157.

13. Chen, F.; Dai, H.; Dong, X.; Yang, J.; Zhong, M. Physical properties of lignin-based polypropylene blends. Polym. Compos. 2011, 32, 1019-1025.

14. Borysiak, S. Fundamental studies on lignocellulose/polypropylene composites: Effects of wood treatment on the transcrystalline morphology and mechanical properties. J. Appl. Polym. Sci. 2013, 127, 1309-1322.

15. Gozdecki, C.; Wilczyński, A.; Kociszewski, M.; Zajchowski, S. Mechanical properties of wood-polypropylene composites with industrial wood particles of different sizes. Wood Fiber. Sci. 2012, 44, 14-21.

16. Guo, X.; Zhang, S.; Shan, X. Adsorption of metal ions on lignin. J. Hazard. Mater. 2008, 151, 134-142.

17. Betancur, M.; Bonelli, P.R.; Velásquez, J.A.; Cukierman, A.L. Potentiality of lignin from the Kraft pulping process for removal of trace nickel from wastewater: Effect of demineralization. Bioresour. Technol. 2009, 100, 1130-1137. 
18. Bulgariu, L.; Bulgariu, D.; Malutan, T.; Macoveanu, M. Adsorption of lead(II) ions from aqueous solution onto lignin. Adsorp. Sci. Technol. 2009, 27, 435-445.

19. Harmita, H.; Karthikeyan, K.G.; Pan, X.J. Copper and cadmium sorption onto kraft and organosolv lignins. Bioresour. Technol. 2009, 100, 6183-6191.

20. Ahmaruzzaman, M. Industrial wastes as low-cost potential adsorbents for the treatment of wastewater laden with heavy metals. Adv. Colloid Interface Sci. 2011, 166, 36-59.

21. Lei, Y.; Huizhen, Y. Modification of reed alkali lignin to adsorption of heavy metals. Adv. Mater. Res. 2013, 622, 1646-1650.

22. Ge, Y.; Li, Z.; Kong, Y.; Song, Q.; Wang, K. Heavy metal ions retention by bi-functionalized lignin: Synthesis, applications, and adsorption mechanisms. J. Ind. Eng. Chem. 2014, 20, 4429-4436.

23. Toh, K.; Yokoyama, H.; Takahashi, C.; Watanabe, T.; Noda, H. Effect of herb lignin on the growth of enterobacteria. J. Gen. Appl. Microbiol. 2007, 53, 201-205.

24. Ehrlich, H. Chitin and collagen as universal and alternative templates in biomineralization. Int. Geol. Rev. 2010, 52, 661-699.

25. Ehrlich, H.; Krautter, M.; Hanke, T.; Simon, P.; Knieb, C.; Heinemann, S.; Worch, H. First evidence of the presence of chitin in skeleton of marine sponges. Part II. Glass sponges. (Hexactinellida: Porifera). J. Exp. Zool. B 2007, 308, 473-478.

26. Ehrlich, H.; Maldonado, M.; Spindler, K.D.; Eckert, C.; Hanke, T.; Born, R.; Goebel, C.; Simon, P.; Heinemann, S.; Worch, H. First evidence of chitin as a component of the skeletal fibers of marine sponges. Part I. Verongidae (Demospongia: Porifera). J. Exp. Zool. B 2007, 308, 347-356.

27. Brunner, E.; Ehrlich, H.; Schupp, P.; Hedrich, R.; Hunoldt, S.; Kammer, M.; Machill, S.; Paasch, S.; Bazhenov, V.V.; Kurek, D.V.; et al. Chitin-based scaffolds are an integral part of the skeleton of the marine demosponge Ianthella basta. J. Struct. Biol. 2009, 168, 539-547.

28. Ehrlich, H.; Ilan, M.; Maldonado, M.; Muricy, G.; Bavestrello, G.; Kljajic, Z.; Carballo, J.L.; Schiaparelli, S.; Ereskovsky, A.; Schupp, P.; et al. Three-dimensional chitin-based scaffolds from Verongida sponges (Demospongiae: Porifera). Part I. Isolation and identification of chitin. Int. J. Biol. Macromol. 2010, 47, 132-140.

29. Yang, T.C.; Zall, R.R. Absorption of metals by natural polymers generated from seafood processing wastes. Ind. Eng. Chem. Prod. Res. Dev. 1984, 23, 168-172.

30. Muzzarelli, R.A.A. Chitins and chitosans for the repair of wounded skin, nerve, cartilage and bone. Carbohydr. Polym. 2009, 76, 167-182.

31. Jayakumar, R.; Nair, A.; Sanoj Rejinold, N.; Maya, S.; Nair, S.V. Doxorubicin-loaded pHresponsive chitin nanogels for drug delivery to cancer cells. Carbohydr. Polym. 2012, 87, 2352-2356.

32. Liu, H.S.; Chen, W.H.; Lai, J.T. Immobilization of isoamylase on carboxymethyl-cellulose and chitin. Appl. Biochem. Biotechnol. 1997, 66, 57-67.

33. Chang, R.C.; Shaw, J.F. The immobilization of Candida cylindracea lipase on PVC, chitin and agarose. Bot. Bull. Acad. Sin. 1987, 28, 33-42.

34. Romo-Sanchez, S.; Arevalo-Villena, M.; Garcia Romero, E.; Ramirez, H.L.; Briones Perez, A. Immobilization of $\beta$-glucosidase and its application for enhancement of aroma precursors in muscat wine. Food Bioprocess Technol. 2014, 7, 1381-1392.

35. Krajewska, B. Application of chitin- and chitosan-based materials for enzyme immobilizations: A review. Enzyme Microb. Technol. 2004, 35, 126-139. 
36. Vaillant, F.; Millan, A.; Millan, P.; Dormier, M.; Decloux, M.; Reynes, M. Co-immobilized pectinlyase and endocellulase on chitin and nylon supports. Process Biochem. 2000, 35, 989-996.

37. Batra, R.; Gupta, M.N. Non-covalent immobilization of potato (Solanum tuberosum) polyphenol oxidase on chitin. Biotechnol. Appl. Biochem. 1994, 19, 209-215.

38. Wang, G.; Xu, J.J.; Ye, L.H.; Zhu, J.J.; Chen, H.Y. Highly sensitive sensors based on the immobilization of tyrosinase in chitosan. Bioelectrochemistry 2002, 57, 33-38.

39. Gomes, F.M.; Pereira, E.B.; de Castro, H.F. Immobilization of lipase on chitin and its use in nonconventional biocatalysis. Biomacromolecules 2004, 5, 17-23.

40. Zeng, J.B.; He, Y.S.; Li, S.L.; Wang, Y.Z. Chitin whiskers: An overwiev. Biomacromolecules 2012, 13, 1-11.

41. Filipkowska, U. Desorption of reactive dyes from modified chitin. Environ. Technol. 2008, 29, 681-690.

42. Jesionowski, T.; Zdarta, J.; Krajewska, B. Enzymes immobilization by adsorption: A review. Adsorption 2014, 20, 801-821.

43. Wong, P.T.T.; Nong, R.K.; Caputo, T.A.; Godwin, T.A.; Rigas, B. Infrared spectroscopy of exfoliated human cervical cells: Evidence of extensive structural changes during carcinogenesis. Proc. Natl. Acad. Sci. USA 1991, 88, 10988-10992.

44. Dousseau, F.; Pezolet, M. Determination of the secondary structure content of proteins in aqueous solutions from their amide I and amide II infrared bands. Comparison between classical and partial least-squares methods. Biochemistry 1990, 29, 8771-8779.

45. Dong, L.; Ge, C.; Qin, P.; Chen, Y.; Xu, Q. Immobilization and catalytic properties of candida lipolytic lipase on surface of organic intercalated and modified MgAl-LDHs. Sol. Sci. 2014, 31, 8-15.

46. Cabrera-Padilla, R.Y.; Lisboa, M.C.; Pereira, M.M.; Figueiredo, R.T.; Franceschi, E.; Fricks, A.T.; Lima, A.S.; Silva, D.P.; Soares, C.M.F. Immobilization of Candida rugosa lipase onto an eco-friendly support in the presence of ionic liquid. Bioprocess Biosyst. Eng. 2014, doi:10.1007/ s00449-014-1322-2.

47. Klapiszewski, Ł.; Zdarta, J.; Szatkowski, T.; Wysokowski, M.; Nowacka, M.; Szwarc-Rzepka, K.; Bartczak, P.; Siwińska-Stefańska, K.; Ehrlich, H.; Jesionowski, T. Silica/lignosulfonate hybrid materials: Preparation and characterization. Cent. Eur. J. Chem. 2014, 12, 719-735.

48. Lavall, R.L.; Assis, O.B.G.; Campana-Filho, S.P. $\beta$-Chitin from the pens of Loligo sp.: Extraction and characterization. Bioresource Technol. 2007, 98, 2465-2472.

49. Jang, M.K.; Kong, B.G.; Jeong, Y.I.; Lee, C.H.; Nah, J.W. Physicochemical characterization of $\alpha$-chitin, $\beta$-chitin, and $\gamma$-chitin separated from natural resources. J. Polym. Sci. A 2004, 42, 3423-3432.

50. Klapiszewski, Ł.; Wysokowski, M.; Majchrzak, I.; Szatkowski, T.; Nowacka, M.; Siwińska-Stefańska, K.; Szwarc-Rzepka, K.; Bartczak, P.; Ehrlich, H.; Jesionowski, T. Preparation and characterization of multifunctional chitin/lignin materials. J. Nanomater. 2013, 1-13, doi:10.1155/2013/425726.

51. Naidja, A.; Liu, C.; Huang, P.M. Formation of protein-birnessite complex: XRD, FTIR, and AFM analysis. J. Colloid Interface Sci. 2002, 251, 46-56.

52. Portaccio, M.; Della Ventura, B.; Mita, D.G.; Manolova, N.; Stoilova, O.; Rashkov, I.; Lepore, M. FT-IR microscopy characterization of sol-gel layers prior and after glucose oxidase immobilization for biosensing applications. J. Sol-Gel Sci. Technol. 2011, 57, 204-211. 
53. Wysokowski, M.; Klapiszewski, Ł.; Moszyński, D.; Bartczak, P.; Szatkowski, T.; Majchrzak, I.; Siwińska-Stefańska, K.; Bazhenov, V.V.; Jesionowski, T. Modification of chitin with kraft lignin and development of new biosorbents for removal of cadmium(II) and nickel(II) ions. Mar. Drugs 2014, 12, 2245-2268.

54. Cardenas, G.; Cabrera, G.; Taboada, E.; Miranda, S.P. Chitin characterization by SEM, FTIR, $\mathrm{XRD}$, and ${ }^{13} \mathrm{C}$ cross polarization/mass angle spinning NMR. J. Appl. Polym. Sci. 2004, 93, 1876-1885.

55. Tomizuka, N.; Ota, Y.; Yamada, K. Lipase from Candida cylindracea II. Amino acid composition, carbohydrate component, and some physical properties. Agric. Biol. Chem. 1966, 30, 1090-1096.

56. Wang, B.; Li, J.; Zhang, J.; Li, H.; Chen, P.; Gu, Q.; Wang, Z. Thermo-mechanical properties of the composite made of poly (3-hydroxybutyrate-co-3-hydroxyvalerate) and acetylated chitin nanocrystals. Carbohydr. Polym. 2013, 95, 100-106.

57. Song, J.; Kahveci, D.; Chen, M.; Guo, Z.; Xie, E.; Xu, X.; Besenbacher, F.; Dong, M. Enhanced catalytic activity of lipase encapsulated in PCL nanofibers. Langmuir 2012, 28, 6157-6162.

58. Briggs, D.; Grant, J.T. Surface Analysis by Auger and X-ray Photoelectron Spectroscopy; IM Publications and SurfaceSpectra Limited: Charlton, UK, 2003.

59. Wang, J.; Wang, Z.; Li, J.; Wang, B.; Liu, J.; Chen, P.; Miao, M.; Gu, Q. Chitin nanocrystals grafted with poly(3-hydroxybutyrate-co-3-hydroxyvalerate) and their effects on thermal behavior of PHBV. Carbohydr. Polym. 2012, 87, 784-789.

60. De Lange, P.J.; Mahy, J.W.G. ToF-SIMS and XPS investigations of fibers, coatings and biomedical materials. Fresenius' J. Anal. Chem. 1995, 353, 487-493.

61. Rouxhet, P.G.; Genet, M.J. XPS analysis of bio-organic systems. Surf. Interface Anal. 2011, 43, 1453-1470.

62. Namboodiri, V.M.H.; Chattaopadhyaya, R. Purification and biochemical characterization of a novel thermostable lipase from Aspergillus niger. Lipids 2000, 35, 495-502.

63. Pokorny, D.; Cimerman, A.; Steiner, W. Aspergillus niger lipases: Induction, isolation and characterization of two lipases from a MZKI Al 16 strain. J. Mol. Cat. B Enzym. 1997, 2, 215-222.

64. Xiaoming, L.; Breddam, K. A novel carboxylesterase from Aspergillus niger and its hydrolysis of succinimide esters. Carlsberg Res. Commun. 1989, 54, 241-249.

65. Rezwan, K.; Studart, A.R.; Vörös, J.; Gauckler, L.J. Change of $\zeta$ potential of biocompatible colloidal oxide particles upon adsorption of bovine serum albumin and lysozyme. J. Phys. Chem. B 2005, 109, 14469-14474.

66. Rezwan, K.; Meier, L.P.; Rezwan, M.; Voros, J.; Textor, M.; Gauckler, L.J. Bovine serum albumin adsorption onto colloidal $\mathrm{Al}_{2} \mathrm{O}_{3}$ particles: A new model based on zeta potential and UV-Vis measurements. Langmuir 2004, 20, 10055-10061.

67. Bernsmann, F.; Frisch, B.; Ringwald, C.; Ball, V. Protein adsorption on dopamine-melanin films: Role of electrostatic interactions inferred from $\zeta$-potential measurements versus chemisorption. J. Colloid Interface Sci. 2010, 344, 54-60.

68. Li, S.; Hu, J.; Liu, B. A study on the adsorption behavior of protein onto functional microspheres. Chem. Technol. Biotechnol. 2005, 80, 531-536. 
69. Bradford, M.M. Rapid and sensitive method for the quantitation of microgram quantities of protein utilizing the principle of protein-dye binding. Anal. Biochem. 1976, 72, 248-254.

70. Sheldon, R.A.; van Pelt, S. Enzyme immobilisation: Why, what and how? Chem. Soc. Rev. 2013, 42, 6223-6235.

71. Abdel-Naby, M.A. Immobilization of Aspergillus niger NRC 107 xylanase and beta-xylosidase, and properties of the immobilzed enzymes. Appl. Biochem. Biotechnol. 1993, 38, 69-81.

72. Jia, J.; Hu, Y.; Liu, L.; Jiang, L.; Zou, B.; Huang, H. Enhancing catalytic performance of porcine pancreatic lipase by covalent modification using functional ionic liquids. ACS Catal. 2013, 3, 1976-1983.

73. Emregul, E.; Sungur, S.; Akbulut, U. Polyacrylamide-gelatine carrier system used for invertase immobilization. Food Chem. 2006, 97, 591-597.

74. Zhu, Y.T.; Ren, X.Y.; Liu, Y.M.; Wei, Y.; Qing, L.S.; Liao, X. Covalent immobilization of porcine pancreatic lipase on carboxyl-activated magnetic nanoparticles: Characterization and application for enzymatic inhibition assays. Mater. Sci. Eng. C Mater Boil. Appl. 2014, 38, 278-285.

75. Melgosa, R.; Sanz, M.T.; Solaesa, A.G.; Bucio, S.L.; Beltran, S. Enzymatic activity and conformational and morphological studies of four commercial lipases treated with supercritical carbon dioxide. J. Supercrit. Fluids 2015, 97, 51-62.

76. Zdarta, J.; Sałek, K.; Kołodziejczak-Radzimska, A.; Siwińska-Stefańska, K.; Szwarc-Rzepka, K.; Norman, M.; Klapiszewski, Ł.; Bartczak, P.; Kaczorek, E.; Jesionowski, T. Immobilization of Amano Lipase A onto Stöber silica surface: Process characterization and kinetic studies. Open Chem. 2015, 13, 138-148.

(C) 2015 by the authors; licensee MDPI, Basel, Switzerland. This article is an open access article distributed under the terms and conditions of the Creative Commons Attribution license (http://creativecommons.org/licenses/by/4.0/). 